\title{
PROSES BERPIKIR SISWA TUNAGRAHITA RINGAN DALAM MEMECAHKAN MASALAH MATEMATIKA BENTUK SOAL CERITA PADA OPERASI HITUNG CAMPURAN
}

\author{
Muhlishotul Hidayah ${ }^{1}$, Imam Sujadi $^{2}$, Pangadi $^{3}$ \\ ${ }^{1,2,3}$ Program Magister Pendidikan Matematika, PPs Universitas Sebelas Maret Surakarta
}

\begin{abstract}
The aim of this research was to describe the thinking process of students with mild mental retardation in solving mathematics problems concerning with story questions in a mixed arithmetic operation. This research was a qualitative case study. The subjects of this research were the students of VIII C SLB Negeri Surakarta consisting of two students: a male and a female students. The procedure of selecting the subject used purposive sampling. The data of the research were collected by using think aloud method. To validate the data, the researcher used time triangulation. The techniques of analyzing the data were: (1) classifying the data into four categories based on Santrock steps: (a) finding and framing the problem, (b) developing problemsolving strategies, (c) evaluating solutions, and (d) rethinking and redefining the problem and solutions, and then reducing the data that are not included in four categories, (2) presenting the data in table, and (3) concluding thinking process of students with mild mental retardation in each category. The results of the research showed that: (a) finding and framing the problem: The two students began the activities by reading the questions, then the students kept silent while reexamining the questions, the students could not mention what was known and what was asked, the students waited for the instruction about what to do, the students could only reveal some information on what was known. To find out the information asked, the one of students got difficulty in mentioning what was asked shown by silent respond then read the questions again, and another student reexamined the questions and revealed the answers related to arithmetic operations. In framing the problem-solving strategy, these two students needed guidance to make strategy by linking the arithmetic operations, and another student also expresses problem-solving strategies that were not appropriate on the first step, (b) developing problem-solving strategies: these two students needed guidance in solving problems, another student solved problems based on the strategy that had been compiled by linking the arithmetic operations, while another student got difficulties when implementing different strategies. In the process of calculating, the students completed the calculation by compiling it downwards, and the students tended to use their hands as a means of calculation, (c) evaluating solutions: the student checked the answer by recalculating the answer, while another student only looked the answer at glance and believed in the answer, (d) rethinking and redefining the problems and solutions: these two students looked at the answer and revealed that no other idea/way in solving the problem.
\end{abstract}

Key words: thinking process, mild mental retardation, problem solving, story questions.

\section{PENDAHULUAN}

Kebijakan pemerintah dalam pendidikan tertuang pada Undang-Undang Dasar

1945 Pasal 31 ayat 1 mengatakan bahwa setiap warga negara mempunyai kesempatan yang sama untuk memperoleh pendidikan. Begitu juga tertuang dalam Undang-Undang No.20 tahun 2003 tentang Sistem Pendidikan Nasional Pasal 5 ayat 2 yang menyatakan bahwa:"Warga negara yang mengalami kelainan fisik, emosional, mental, intelektual dan atau sosial berhak memperoleh pendidikan khusus."Hal ini berarti bahwa anak yang 
mengalami kelainan dalam penglihatan (tunanetra), pendengaran (tunarungu), proses mental (tunagrahita), memfungsikan sebagian anggota badan (tunadaksa), tingkah laku (tunalaras) dan anak yang mengalami kesulitan belajar berhak memperoleh kesempatan yang sama dalam dunia pendidikan. Pendidikan harus dilaksanakan secara merata tanpa pengecualian, diantaranya sekolah negeri, sekolah swasta, bahkan Sekolah Luar Biasa (SLB) juga menjadi tempat formal dalam dunia pendidikan.

Sekolah Luar Biasa adalah sekolah yang dirancang khusus untuk anak-anak yang mengalami hambatan dari satu atau lebih jenis kelainan, yaitu kelainan fisik, mental, maupun sosial. Dalam setiap SLB akan lebih mengkhususkan menerima siswa dengan kelainan yang berbeda-beda, misalnya pada SLB Negeri Surakarta yang merupakan salah satu sekolah SLB Negeri yang memberikan pelayanan pendidikan kepada anak dengan kelainan tertentu, diantaranya: tunarungu (kelainan pada pendengaran), tunagrahita (kelainan pada mental), tunadaksa (kelainan fisik pada otot, tulang, dan sendi), dan autis.

Pendidikan khusus yang diberikan pada siswa tunagrahita, bertujuan untuk mengembangkan kemampuannya secara optimal disesuaikan dengan kemampuan dan potensi mereka. Istilah yang digunakan untuk siswa tunagrahita adalah siswa yang memiliki perkembangan intelegensi yang lambat atau keterbelakangan mental dibawah anak normal. Banyak yang berasumsi bahwa anak tunagrahita sama dengan anak idiot, padahal asumsi tersebut kurang tepat karena sesungguhnya siswa tunagrahita terdiri atas beberapa klasifikasi, setiap klasifikasi pada siswa tunagrahita selalu diukur dengan tingkat IQ (Intelegensi Question), yang terbagi menjadi tiga klasifikasi sebagai berikut. (1) Tunagrahita ringan yang disebut tunagrahita mampu didik (debil), siswa tunagrahita ringan tersebut mampu untuk diarahkan dan dididik dalam bidang akademik (membaca, menulis, dan berhitung), keahlian sosial dan lain-lain. Siswa tunagrahita ringan lebih mudah diajak berkomunikasi. Selain itu kondisi fisik mereka tidak begitu mencolok, tampak seperti orang normal pada umumnya, dan mereka mampu berlindung dari bahaya apapun, karena itu siswa tunagrahita ringan tidak memerlukan pengawasan ekstra. (2) Tunagrahita sedang yang disebut mampu latih (imbesil), siswa tunagrahita sedang hanya mampu dilatih oleh tenaga pendidik dalam mengasah kemampuannya, siswa tersebut sulit dalam hal akademik, tetapi mampu dilatih dalam mengurus dirinya dan selalu membutuhkan pengawasan secara terus menerus. (3) Tunagrahita berat yang disebut mampu rawat (idiot), siswa tunagrahita berat tersebut hanya mampu dirawat dalam kegiatan sehari-hari, mereka membutuhkan pengawasan, perhatian, bahkan pelayanan secara total, sehingga mereka memerlukan perlindungan dari bahaya sepanjang hidupnya (Sutjihati Somantri, 2007: 108). Kirk \& Johnson (dalam Mohammad Efendi, 2006:90) menyatakan bahwa "A child who is an idiot is so low intellectually that he does no learn 
to talk and usually does learn to take care of his bodily need ". Anak dengan kategori idiot adalah anak dengan kecerdasan intelektual rendah dan mereka tidak dapat mengurus dirinya sendiri dan tidak mampu terus hidup tanpa bantuan orang lain. Dalam hal ini terlihat bahwa asumsi pada siswa tunagrahita sama dengan anak idiot lebih tepatnya digunakan jika siswa tunagrahita tersebut tergolong dalam klasifikasi siswa tunagrahita berat.

Siswa tunagrahita ringan adalah siswa dengan kemampuan kecerdasan rata-rata dibawah siswa normal, keterhambatan prilaku adaptif, dan terhambat dalam masa perkembangan. Tetapi siswa tersebut mampu dididik dalam bidang akademik (membaca, berhitung dan menulis), sosial dan pekerjaan. Sedangkan, untuk kemampuan kognitif (dalam hal persepsi, ingatan, pengembangan ide, penilaian dan penalaran), siswa tunagrahita ringan akan berkembang tetapi tidak sebaik siswa normal. Kemampuan bernalar dan berpikir siswa tunagrahita ringan terlihat dengan menyelesaikan permasalah tertkait permasalahan matematika.

Mengetahui proses berpikir siswa, terutama pada siswa tunagrahita ringan/siswa mampu didik pada saat memecahkan masalah matematika sangat penting untuk diketahui seorang pendidik. Karena pendidik dapat melacak letak dan jenis kesalahan yang dilakukan oleh siswa tunagrahita ringan ketika dalam proses pemecahan masalah. Kesalahan yang dilakukan dapat dijadikan sumber informasi belajar dan pemahaman bagi siswa tunagrahita ringan tersebut, selain itu pendidik dapat merancang pembelajaran yang sesuai dengan kemampuan siswa tunagrahita ringan.

Menurut Breen and O'shea (2010),"In order to develop mathematically, it is necessary for learners of mathematics not only to master new mathematical content but also to develop a wide range of thinking skills". Maksudnya bahwa dalam rangka mengembangkan matematika perlu bagi peserta didik tidak hanya untuk menguasai isi matematika tapi juga untuk mengembangkan bagaimana keterampilan atau kemampuan berpikir dalam memecahkan masalah matematika.

Untuk dapat memecahkan masalah matematika dibutuhkan suatu proses berpikir yang optimal. Proses berpikir adalah aktivitas kognitif siswa yang dimulai dari menerima masalah, menggunakan informasi yang telah ada sehingga didapatkan penyelesaian dari masalah. Aktivitas kognitif yang terjadi disertai dengan ekpresi verbal siswa, yaitu siswa mengekspresikan ide mereka dengan berbicara ketika menyelesaikan soal cerita. Soal cerita termasuk bagian dari soal untuk mengukur kemampuan siswa dalam memahami pelajaran matematika dan melatih perkembangan proses berpikir siswa. Soal cerita yang dimaksud erat kaitannya dengan masalah yang ada dalam kehidupan siswa sehari-hari, dan apabila diaplikasikan kedalam dunia matematika berarti soal cerita yang untuk dicari 
penyelesaiannya dengan menggunakan kalimat matematika yang terkait pada operasi hitung (+, -, x, : ). Menurut Solso (2007: 402), berpikir merupakan proses yang menghasilkan representasi mental baru melalui transformasi informasi oleh interaksikompleks dari atribusi mental yang mencakup penilaian, pengabstrakan, penalaran, pengambaran, kreativitas, kecerdasan dan pemecahan masalah. Proses berpikir akan menghasilkan suatu pengetahuan baru yang merupakan transformasi atas informasiinformasi yang didapat sebelumnya dalam pemecahan masalah.

Menurut Pehkonen (2000: 52),

"Problem solving has generally been accepted as a means for advancing thinking skills and Solving problems is not only a goal of learning mathematics but also a major means of doing so. In everyday life and in the workplace, being a good problem solver can lead to great advantages. Problem solving is an integral part of all mathematics learning".

Maksudnya bahwa pemecahan masalah secara umum diterima sebagai alat untuk memajukan keterampilan dalam berpikir dan memecahkan masalah tidak hanya bertujuan dalam pembelajaran matematika tetapi juga merupakan sarana utama untuk pelajaran yang lain atau kegiatan yang lain. Dalam memecahkan masalah matematika berkaitan dengan soal cerita pada operasi hitung campuran dapat diamati dengan langkah pemecahan masalah oleh Santrock (2009), diantaranya ketika siswa: (1) menemukan dan menyusun masalah, jika siswa tersebut mampu mengidentifikasikan hal apa yang diketahui dan apa yang ditanyakan, dan menyusun masalah untuk menemukan strategi atau rencana penyelesaian masalah. (2) mengembangkan strategi pemecahan masalah, jika siswa mampu menggunakan algoritma (strategi yang menjamin solusi atas satu persoalan) dalam melaksanakan rencana penyelesaian masalah. (3) mengevaluasi solusi, jika siswa tersebut dapat mengecek ulang dari hasil jawaban yang sudah dikerjakan dan meyakininya. (4) memikirkan serta mendefinisikan kembali masalah dan solusi, jika siswa menemukan ide/cara lain dalam pemecahan masalah. Dalam proses pemecahan masalah maka terjadilah suatu proses berpikir siswa dengan mengungkapkan segala bentuk pengetahuan yang dimiliki secara verbal dan tertulis untuk menyelesaikan soal tersebut.

Berdasarkan penelitian terhadap siswa tunagrahita yang dilakukan Butler, dkk (2001) mengemukakan hasil penelitiannya bahwa siswa tunagrahita ringan mampu diberikan pelajaran matematika, dilihat dari kemampuan kognitif siswa tunagrahita ringan dapat berkembang, ketika diberikan permasalahan matematika dengan bantuan intruksi secara langsung. Sandie (2013), dalam peneltiannya yang berjudul proses berpikir siswa tunagrahita dalam pemecahan masalah matematika ditinjau dari perbedaan gender menyatakan bahwa: (1) pada tahap pembentukan konsep dalam proses berpikir, siswa 
laki-laki dan perempuan memiliki kesamaan pernyataan dalam mengemukakan jawaban dan alasan, (2) pada tahap logika dalam proses berpikir, terdapat perbedaan pernyataan antara siswa laki-laki dan perempuan, (3) pada tahap pengambilan keputusan dalam proses berpikir, siswa laki-laki dan perempuan memiliki kesamaan pernyataan dalam mengemukakan jawaban.

Berdasarkan hasil penelitian yang telah dilakukan diatas, dapat terlihat bahwa anak tunagrahita terutama siswa tunagrahita ringan mampu mengemukakan idenya, dan mampu dalam bidang akademik. Sehingga dalam hal ini, peneliti tertarik dan ingin mengetahui lebih jauh tentang bagaimana proses berpikir siswa tunagrahita ringan kelas VIII C dalam memecahkan masalah terutama pada bentuk soal cerita operasi hitung campuran.

\section{METODE PENELITIAN}

Jenis penelitian ini adalah penelitian kualitatif studi kasus yaitu penelitian yang mendeskripsian suatu masalah dengan pengambilan data yang mendalam mengenai kondisi sebenarnya di lapangan. Penelitian ini dilaksanakan di SLB Negeri Surakarta. Subjek penelitian ini adalah 2 orang siswa tunagrahita ringan pada kelas VIII C yang terdiri atas 1 orang siswa laki-laki dan 1 orang siswa perempuan, dengan pertimbangan 1) siswa tersebut mengalami ganguan mental yang disebut tunagrahita kategori ringan, 2) siswa sudah mendapatkan materi operasi hitung campuran, 3) siswa mampu berkomunikasi terkait mengungkapkan idenya secara verbal dan tertulis. Pemilihan subjek penelitian dengan cara purposive sampling, dengan kriteria pemilihan subjek sebagai berikut. 1) Siswa telah mempelajari operasi hitung campuran, 2) siswa mampu menyelesaikan soal tes awal, dan 3) siswa mampu berkomunikasi terkait atas gagasan atau idenya secara verbal dan tertulis.

Pengumpulan data dilakukan dengan cara think aloud method. Siswa diminta untuk menyelesaikan masalah disertai ungkapan verbal atas ide yang dipikirkan. Setelah dilakukan pengambilan data pertama dan data kedua pada masing-masing subjek, kemudian ditriangulasi waktu untuk mendapatkan data yang valid. Data dikatakan valid apabila terdapat konsistensi pada hasil pengumpulan data pertama dan pengumpulan data kedua, serta kedua data tersebut menggambarkan proses berpikir siswa tunagrahita ringan.

Untuk mendapatkan data proses berpikir siswa tunagrahita ringan, digunakan instrumen utama dan instrumen bantu. Instrumen utama yaitu peneliti sendiri yang berinteraksi secara langsung dengan subjek penelitian. Intrumen bantu berupa soal tes cerita yang divalidasi terlebih dahulu oleh validator. Teknik analisis data dilakukan 
dengan cara: (1) mengelompokkan data dalam empat kategori sesuai dengan langkah pemecahan masalah Santrock, yaitu a) menemukan dan menyusun masalah, b)mengembangkan strategi pemecahan masalah, c) mengevaluasi solusi, dan d) memikirkan serta mendefinisikan kembali masalah dan solusi; kemudian mereduksi data yang tidak termasuk dalam empat kategori tersebut, (2) menyajikan data dalam bentuk tabel, dan (3) menyimpulkan proses berpikir siswa tunagrahita ringan pada masingmasing kategori.

\section{HASIL PENELITIAN DAN PEMBAHASAN}

Pengumpulan data dilakukan setelah didapatkan siswa yang memenuhi kriteria pemilihan subjek pada penelitian, dan didapatkan 2 orang siswa tunagrahita ringan yang terdiri atas 1 orang siswa laki-laki (dengan inisial siswa DN) dan 1 orang siswa perempuan (dengan inisial siswa FT) yang berpotensi dalam mendapatkan data sesuai dengan tujuan penelitian. Selanjutnya, dilakukan pengambilan data melalui 2 kali tes dengan waktu yang berbeda. Data dianalisis dan dikategorikan berdasarkan langkah pemecahan masalah Santrock yaitu, menemukan dan menyusun masalah, mengembangkan strategi pemecahan masalah, mengevaluasi solusi, dan memikirkan serta mendefiniskan kembali masalah dan solusi. Untuk memperoleh data yang valid dilakukan triangulasi waktu dengan membandingkan hasil tes data pertama dan tes data kedua pada setiap subjek. Kemudian didapatkan data yang sama sebagai data yang valid dan data yang berbeda akan direduksi. Hasil data yang valid tersebut pada kedua subjek dibandingkan, sehingga dapat disimpulkan gambaran proses berpikir siswa tunagrahita ringan dalam memecahkan masalah bentuk soal cerita pada operasi hitung campuran.

Analisis proses berpikir siswa tunagrahita ringan pada kedua subjek (siswa DN dan siswa FT) berdasarkan langkah Santrock. Hasil analisis data pertama dan data kedua pada siswa DN disajikan pada Tabel 1.

Tabel 1. Hasil Data Pertama dan Data Kedua pada Siswa DN

\begin{tabular}{lllll}
\hline \multicolumn{1}{c}{ Langkah } & \multicolumn{2}{c}{ Data Pertama } & \multicolumn{2}{c}{ Data Kedua } \\
\hline Santrock & Menemukan dan & Siswa membaca soal dengan & 1. Siswa membaca soal \\
menyusun & jelas ketika diberikan soal tes. & dengan jelas ketika diberikan \\
masalah & 2. Siswa banyak diam dan melihat- & soal tes. & \\
& lihat kembali soal & & $2 . \quad$ Siswa banyak diam \\
& 3. Siswa menunggu arahan atas & dan melihat-lihat kembali soal. \\
& apa yang dikerjakan. & & $3 . \quad$ Siswa menunggu \\
& 4. Siswa kesulitan menyebutkan & arahan atas apa yang \\
& halyang diketahui dan hal yang & dikerjakan. & \\
& ditanyakan. & Siswa mengungkapkan sebagian & menyebutkan & kesulitan \\
& $5 . \quad$ halyang \\
& informasi atas hal yang diketahui. & diketahui dan hal yang \\
\hline
\end{tabular}




\begin{tabular}{|c|c|c|}
\hline $\begin{array}{l}\text { Langkah } \\
\text { Santrock }\end{array}$ & Data Pertama & Data Kedua \\
\hline & $\begin{array}{l}\text { 6. Siswa kesulitan menyebutkan } \\
\text { hal yang ditanya dengan menunjukka } n \\
\text { respon diam lama kemudian membaca } \\
\text { kembali soal. } \\
7 \text { Siswa butuh arahan dalam } \\
\text { menyusun strategi penyelesaian } \\
\text { masalah, dengan menunjukkan respon } \\
\text { diam dan melihat kembali soal, } \\
\text { kemudian baru mampu mengungkapkan } \\
\text { dengan mengkaitkan pada operasi } \\
\text { hitung. }\end{array}$ & $\begin{array}{l}\text { ditanyakan. } \\
5 . \quad \text { Siswa mengungkapkan } \\
\text { sebagian informasi atas hal } \\
\text { yang diketahui. } \\
6 \text {. Siswa kesulitan } \\
\text { menyebutkan hal yang ditanya } \\
\text { dengan menunjukkan respon } \\
\text { diam lama kemudian membaca } \\
\text { kembali soal. } \\
7 \text { Siswa butuh arahan } \\
\text { dalam menyusun strategi } \\
\text { penyelesaian masalah, dengan } \\
\text { menunjukkan respon diam dan } \\
\text { melihat kembali soal, } \\
\text { kemudian baru mampu } \\
\text { mengungkapkan } \\
\text { mengkaitkan pada operasi } \\
\text { hitung. }\end{array}$ \\
\hline $\begin{array}{l}\text { Mengembangka } \\
\text { n strategi } \\
\text { pemecahan } \\
\text { masalah }\end{array}$ & $\begin{array}{l}\text { 1. Siswa butuh arahan dalam } \\
\text { menyelesaikan stretegi yang telah } \\
\text { direncanakan. } \\
\text { 2. Siswa melaksanakan strategi } \\
\text { yang berbeda pada langkah awal } \\
\text { penyelesaian soal. } \\
\text { 3. iswa menyelesaikan masalah } \\
\text { sesuai strategi yang telah disusun } \\
\text { dengan mengkaitkan pada operasi } \\
\text { hitung. Siswa } \\
\text { 4. Senyelesaikan } \\
\text { perhitungan dengan cara dibumbung } \\
\text { susun } \\
\text { (susun kebawah). } \\
\text { Siswa cenderung menggunakan kedua } \\
\text { tangannya sebagai alat bantu hitung. }\end{array}$ & 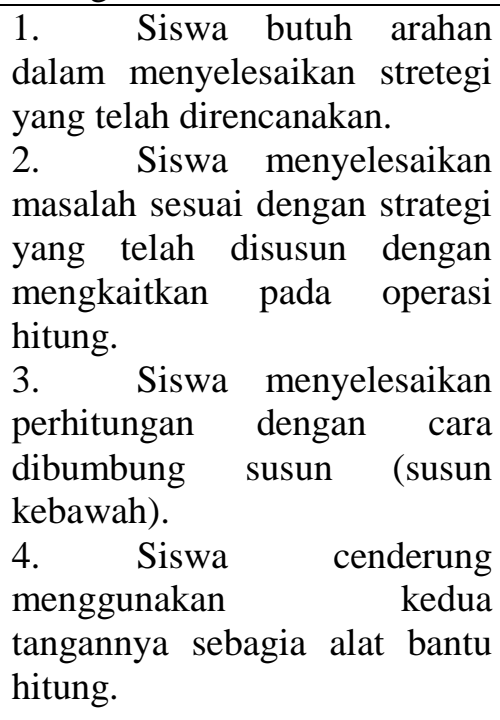 \\
\hline $\begin{array}{l}\text { Mengevaluasi } \\
\text { solusi }\end{array}$ & $\begin{array}{l}\text { 1. Siswa mengecek kembali } \\
\text { dengan menghitung ulang jawaban } \\
\text { didapatkan hasil jawaban yang berbeda, } \\
\text { dan menyakinnya. }\end{array}$ & $\begin{array}{l}1 . \quad \text { Siswa mengecek } \\
\text { kembali dengan menghitung } \\
\text { ulang didapatkan hasil } \\
\text { jawaban yangsama, dan } \\
\text { menyakininya. }\end{array}$ \\
\hline $\begin{array}{l}\text { Memikirkan } \\
\text { serta } \\
\text { mendefinisikan } \\
\text { kembali masalah } \\
\text { dan solusi }\end{array}$ & $\begin{array}{l}\text { 1. Siswa melihat kembali jawaban } \\
\text { dan mengungkapkan bahwa tidak ada } \\
\text { ide/cara lain dalam penyelesaian } \\
\text { masalah. }\end{array}$ & $\begin{array}{l}\text { 1. Siswa melihat kembali } \\
\text { jawaban dan mengungkapkan } \\
\text { bahwa tidak ada ide/cara lain } \\
\text { dalam penyelesaian masalah. }\end{array}$ \\
\hline
\end{tabular}

Berikut hasil analisis proses berpikir siswa tunagrahita ringan pada siswa FT berdasarkan langkah Santrock. Hasil analisis data pertama dan data kedua oleh siswa FT disajikan pada Tabel 2. 
Tabel 2. Hasil Data Pertama dan Data Kedua pada Siswa FT

Data Kedua

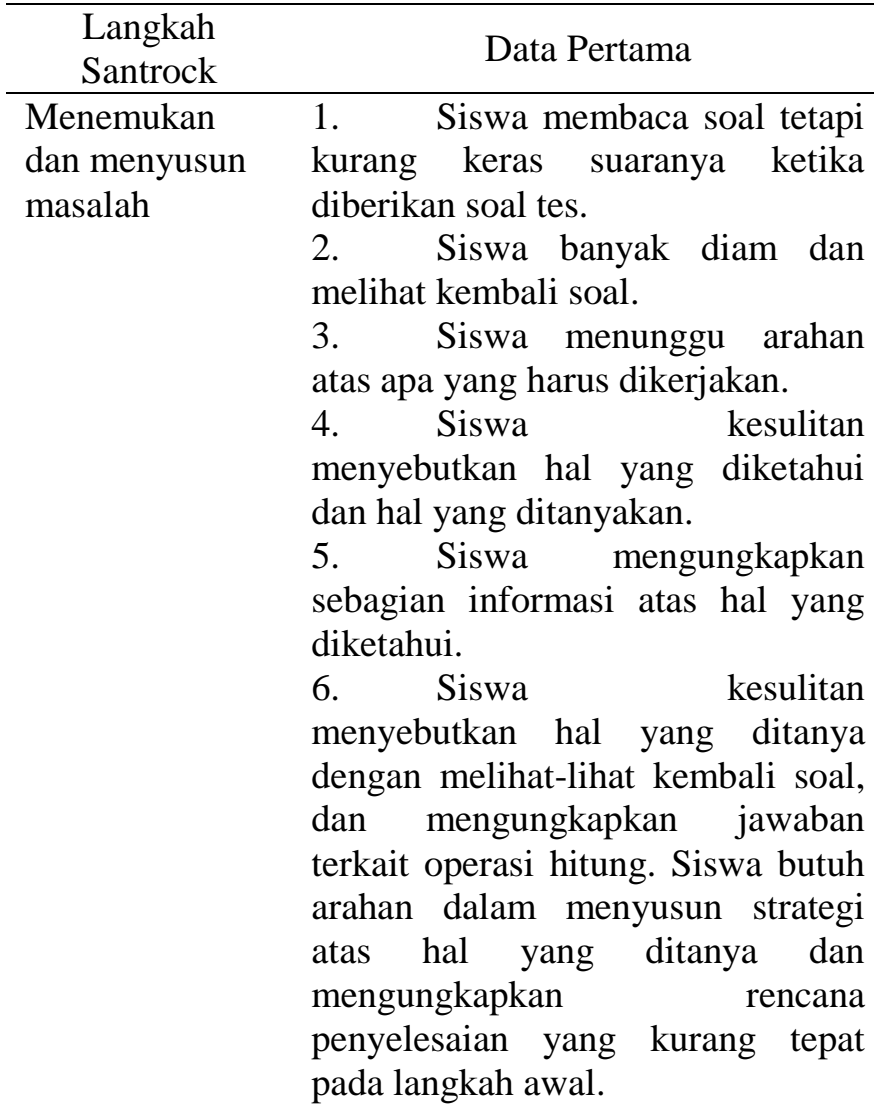

$\begin{array}{ll}\text { Mengembangka } & 1 . \quad \text { Siswa butuh arahan ketika } \\ \text { n strategi } & \text { menyelesaikan masalah atas strategi } \\ \text { pemecahan } & \text { yang telah disusun. }\end{array}$
masalah kurang keras suaranya ketika diberikan soal tes.

2. Siswa banyak diam dan melihat kembali soal.

3. Siswa menunggu arahan atasa apa yang harus dikerjakan.

4. Siswa kesulitan

menyebutkan hal yang diketahui dan hal yang ditanyakan.

5. Siswa mengungkapkan sebagian informasi atas hal yang diketahui.

6. Siswa kesulitan menyebutkan hal yang ditanya dengan melihat-lihat kembali soal, dan mengungkapkan jawaban terkait operasi hitung.

7. Siswa kesulitan dalam menuliskan kata yang diungkapkan.

8. Siswa butuh arahan dalam menyusun strategi atas hal yang ditanya dan mengungkapkan rencana penyelesaian yang kurang tepat pada langkah awal

1. Siswa butuh arahan ketika menyelesaikan masalah atas strategi yang telah disusun.

2. Siswa kesulitan menyelesaikan masalah atas strategi yang telah disusun dengan melaksanakan strategi yang berbeda dan kesalahan proses perhitungan.

3. Siswa kurang teliti dalam menuliskan angka atas informasi dalam soal.

4. Siswa melakukan perhitungan dengan cara dibumbung susun (susun kebawah). 5. Siswa cenderung menggunakan kedua tangannya sebagai alat bantu hitung.

6. Siswa kesulitan membaca lambang bilangan pada nilai puluh ribuan

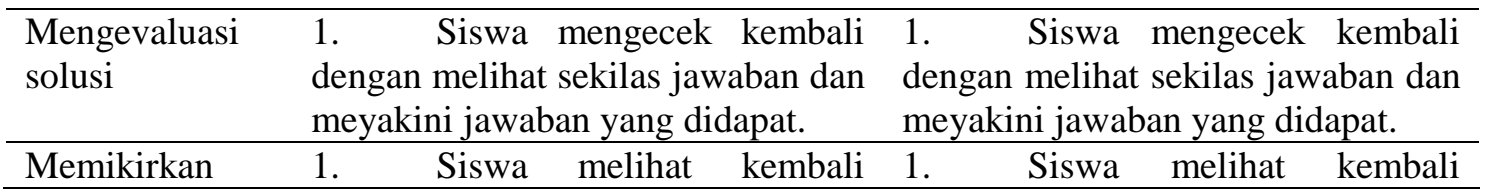

2. Siswa kesulitan menyelesaikan masalah atas strategi yang telah disusun dengan melaksanakan strategi yang berbeda dan kesalahan atas prosedur pengerjaan.

3. Siswa melakukan perhitungan dengan cara dibumbung susun (susun kebawah). 4. Siswa cenderung menggunakan kedua tangannya sebagai alat bantu hitung.

5. Siswa kurang teliti menuliskan angka atas informasi dalam soal. 


\begin{tabular}{|c|c|c|}
\hline $\begin{array}{l}\text { Langkah } \\
\text { Santrock }\end{array}$ & Data Pertama & Data Kedua \\
\hline $\begin{array}{l}\text { serta } \\
\text { mendefinisikan } \\
\text { kembali } \\
\text { masalah dan } \\
\text { solusi }\end{array}$ & $\begin{array}{l}\text { jawaban dan mengungkapkan } \\
\text { bahwa tidak ada ide/cara lain dalam } \\
\text { penyelesaian masalah. }\end{array}$ & $\begin{array}{l}\text { jawaban dan mengungkapkan } \\
\text { bahwa tidak ada ide/cara lain dalam } \\
\text { penyelesaian masalah. }\end{array}$ \\
\hline
\end{tabular}

Berdasarkan hasil data pertama dan data kedua pada setiap subjek di atas, akan dibandingkan dengan di triangulasi waktu sehingga didapatkan data yang sama sebagai data yang valid dan data yang berbeda akan direduksi. Selanjutnya data yang valid pada setiap subjek dibandingkan, sehingga didapatkan kesimpulan proses berpikir siswa tunagrahita ringan dalam memecahkan masalah matematika soal bentuk cerita pada operasi hitung bilangan campuran. Berikut analisis perbandingan kedua subjek pada siswa DN dan siswa FT dapat dilihat pada Tabel 3. Sebagai berikut.

\section{Tabel 3.Analisis Perbandingan Data pada Kedua Subjek}

\begin{tabular}{|c|c|c|}
\hline $\begin{array}{l}\text { Langkah } \\
\text { Santrock }\end{array}$ & Data Valid Siswa DN & Data Valid Siswa FT \\
\hline $\begin{array}{l}\text { Menemukan dan } \\
\text { menyusun } \\
\text { masalah }\end{array}$ & $\begin{array}{l}\text { a. Siswa membaca soal } \\
\text { dengan jelas ketika diberikan soal } \\
\text { tes. } \\
\text { b. Siswa banyak diam dan } \\
\text { melihat-lihat kembali soal. } \\
\text { c. Siswa menunggu arahan } \\
\text { atas apa yang dikerjakan. } \\
\text { d. Siswa kesulitan } \\
\text { menyebutkan halyang diketahui } \\
\text { dan yang ditanyakan. } \\
\text { e. Siswa mengungkapkan } \\
\text { sebagian informasi atas hal yang } \\
\text { diketahui. } \\
\text { f. Siswa kesulitan } \\
\text { menyebutkan hal yang ditanya } \\
\text { dengan diam lama kemudian } \\
\text { membaca kembali soal. } \\
\text { g. Siswa butuh arahan } \\
\text { dalam menyusun strategi } \\
\text { penyelesaian masalah dengan } \\
\text { menunjukkan respon diam dan } \\
\text { melihat kembali soal, kemudian } \\
\text { baru mampu mengungkapkan } \\
\text { dengan mengkaitkan pada operasi } \\
\text { hitung. }\end{array}$ & $\begin{array}{l}\text { a. Siswa membaca soal tetapi } \\
\text { kurang keras suaranya ketika } \\
\text { diberikan soal tes. } \\
\text { b. Siswa banyak diam dan } \\
\text { melihat kembali soal. } \\
\text { c. Siswa menunggu arahan } \\
\text { atas apa yang harus dikerjakan. } \\
\text { d. Siswa kesulitan } \\
\text { menyebutkan hal yang diketahui } \\
\text { dan hal yang ditanyakan. } \\
\text { e. Siswa mengungkapkan } \\
\text { sebagian informasi atas hal yang } \\
\text { diketahui. } \\
\text { f. Siswa kesulitan } \\
\text { menyebutkan hal yang ditanya } \\
\text { dengan melihat-lihat kembali soal, } \\
\text { dan mengungkapkan jawaban } \\
\text { terkait operasi hitung. } \\
\text { g. Siswa butuh arahan dalam } \\
\text { menyusun strategi atas hal yang } \\
\text { ditanya dan mengungkapkan } \\
\text { rencana penyelesain yang kurang } \\
\text { tepat pada langkah awal. }\end{array}$ \\
\hline $\begin{array}{l}\text { Mengembangka } \\
\text { n strategi } \\
\text { pemecahan } \\
\text { masalah }\end{array}$ & $\begin{array}{l}\text { a. Siswa butuh arahan } \\
\text { dalam menyelesaikan strategi } \\
\text { yang telah direncanakan. } \\
\text { b. Siswa menyelesaikan } \\
\text { masalah sesuai strategi yang telah } \\
\text { disusun dengan mengkaitkan pada } \\
\text { operasi hitung. }\end{array}$ & $\begin{array}{l}\text { a. Siswa butuh arahan ketika } \\
\text { menyelesaikan masalah atas } \\
\text { strategi yang telah disusun. } \\
\text { b. Siswa kesulitan } \\
\text { menyelesaikan masalah atas } \\
\text { strategi yang telah disusun dengan } \\
\text { melaksanakan strategi yang }\end{array}$ \\
\hline
\end{tabular}




\begin{tabular}{|c|c|c|}
\hline $\begin{array}{l}\text { Langkah } \\
\text { Santrock }\end{array}$ & Data Valid Siswa DN & Data Valid Siswa FT \\
\hline & $\begin{array}{lll}\text { c. } & \text { Siswa menyelesaikan }\end{array}$ & berbeda. \\
\hline & perhitungan dengan cara & c. Siswa \\
\hline & susun (disusun & perhitungan \\
\hline & kebawah). & $\begin{array}{l}\text { dibumbung } \\
\text { kebawah) }\end{array}$ \\
\hline & menggunakan kedua tangannya & d. Siswa cenderung \\
\hline & sebagai alat bantu hitung. & menggunakan kedua tangannya \\
\hline & & sebagai alat bantu hitung. \\
\hline & & $\begin{array}{l}\text { e. Siswa kurang teliti } \\
\text { menuliskan angka atas informasi } \\
\text { dalam soal. }\end{array}$ \\
\hline Menge & $\begin{array}{lll}\text { a. } & \text { Siswa } & \text { mengecek }\end{array}$ & $\begin{array}{lll}\text { a. } & \text { Siswa mengecek kembali }\end{array}$ \\
\hline solusi & $\begin{array}{l}\text { kembalidengan menghitung ulang } \\
\text { jawaban dan menyakininya. }\end{array}$ & $\begin{array}{l}\text { dengan melihat sekilas jawaban, } \\
\text { dan meyakini atas jawaban yang } \\
\text { didapat. }\end{array}$ \\
\hline $\begin{array}{l}\text { Memikirkan } \\
\text { serta } \\
\text { mendefinisikan } \\
\text { kembali masalah } \\
\text { dan solusi }\end{array}$ & $\begin{array}{l}\text { a. Siswa melihat kembali } \\
\text { jawaban dan mengungkapkan } \\
\text { bahwa tidak ada ide/cara lain } \\
\text { dalam penyelesaian masalah. }\end{array}$ & $\begin{array}{l}\text { a. Siswa melihat kembali } \\
\text { jawaban dan mengungkapkan } \\
\text { bahwa tidak ada ide/cara lain } \\
\text { dalam penyelesaian masalah. }\end{array}$ \\
\hline
\end{tabular}

Berdasarkan analisis perbandingan kedua subjek (siswa DN dan siswa FT) di atas, terlihat adanya persamaan dan perbedaan pada proses berpikir siswa tunagrahita ringan dalam memecahkan masalah berdasarkan langkah Santrock. Dalam kategori menemukan dan menyusun masalah, persamaannya adalah ketika dihadapkan pada soal siswa memulainya dengan membaca soal, kemudian respon siswa diam dan melihat kembali soal, siswa menunggu arahan atas apa yang harus dikerjakan, siswa kesulitan menyebutkan hal yang diketahui dan hal yang ditanyakan, siswa hanya mampu mengungkapkan sebagian informasi atas hal yang diketahui. Sedangkan perbedaannya, untuk menemukan hal yang ditanya, siswa DN kesulitan menyebutkan hal yang ditanya dengan menunjukkan respon diam kemudian membaca kembali soal untuk menemukan jawaban, sedangkan siswa FT menunjukkan respon dengan melihat kembali soal dan mengungkapkan jawaban terkait operasi hitung. Dalam menyusun strategi pemecahan masalah, kedua siswa sama-sama butuh arahan dalam menyusun strategi penyelesaian masalah atas hal yang ditanyakan, sedangkan perbedaannya, siswa DN dengan menunjukkan respon diam dan melihat-lihat kembali soal kemudian baru mampu mengungkapkan dengan mengkaitkan pada operasi hitung, untuk siswa FT kesulitan dengan mengungkapkan strategi yang kurang tepat pada langkah awal. Dalam kategori menemukan dan menyusun masalah, dapat terlihat bahwa siswa tersebut mampu membaca dan mengkomunikasikan informasi dalam soal dengan bentuk ungkapannya secara verbal dan tertulis, siswa butuh arahan sehingga mampu menyusun strategi atas hal yang ditanya dengan mengkaitkan pada operasi hitung dan ada siswa yang kesulitan 
dengan mengungkapkan rencana penyelesain yang kurang tepat. Hal tersebut sesuai dengan yang diungkapkan Mohammad Effendi dan organisasi American Association on Mental Reatardation/AAMR (dalam Ilham Sunaryo dan Surtikanti, 2011: 57) mengatakan bahwa keterbelakangan mental menunjukkan dalam fungsi intelektual dibawah rata-rata, dan keterbatasan pada dua atau lebih keterampilan adaptif, seperti komunikasi, merawat diri, keterampilan sosial, kesehatan, fungsi akademis (membaca, menulis, berhitung), pekerjaan, dll.

Dalam mengembangkan strategi pemecahan masalah, persamaan siswa tunagrahita ringan adalah ketika menyelesaikan soal, siswa butuh arahan ketika akan menyelesaikan permasalahan, siswa menyelesaikan perhitungan dengan cara disusun kebawah, dan siswa cenderung menggunakan kedua tangannya sebagai alat bantu hitung, karena kemampuannya yang terbatas dan cara berpikirnya secara kongkrit. Sedangkan perbedannya adalah ketika menyelesaikan masalah, siswa DN melaksanakan sesuai strategi yang telah disusun dengan mengkaitkan pada operasi hitung, sedangkan siswa FT kesulitan dengan melaksanakan strategi yang berbeda. Siswa FT juga kurang teliti dalam menuliskan angka atas informasi dalam soal, sehingga hasil yang didapat kurang tepat dan terjadi kesalahan dalam perhitungan. Dalam Hal ini, untuk kategori mengembangkan strategi pemecahan masalah terbukti bahwa siswa tunagrahita ringan terlihat mampu dalam hal berhitung, dan siswa tunagrahita tidak mampu mendeteksi kesalahan-kesalahan dalam pernyataan, sesuai dengan karakteristik akademis dan mental. (Ilham Sunaryo dan Surtikanti, 2011:50).

Dalam mengevaluasi solusi, persamaannya adalah kedua siswa sama-sama melakukan pengecekan kembali jawaban, sedangkan perbedaanya pada saat cara yang dipilih siswa DN melakukan pengecekan dengan menghitung ulang jawaban, sedangkan siswa FT dengan melihat sekilas jawaban dan meyakini atas jawaban yang didapat. Dalam memikirkan serta mendefinisikan kembali masalah dan solusi, persamaanya adalah kedua siswa tersebut memberikan respon yang sama dengan melihat kembali jawaban dan mengungkapkan bahwa tidak ada ide/cara lain dalam penyelesaian masalah, dan tidak ada perbedaan dalam kategori tersebut. Sesuai dengan karakteristik mental anak tunagrahita bahwa mereka terbatas kemampuannya dalam penalarannya dan visualisasinya. (Ilham Sunaryo dan Surtikanti, 2011:50).

\section{SIMPULAN DAN SARAN}

Berdasarkan hasil analisis dengan 2 subjek penelitian yang terdiri atas 1 orang siswa laki-laki dan 1 orang siswa perempuan yang sesuai dengan kriteria pemilihan subjek, maka dapat diperoleh kesimpulan bahwa proses berpikir siswa tunagrahita ringan 
kelas VIII C dalam memecahkan masalah matematika bentuk soal cerita pada operasi hitung campuran berdasarkan langkah Santrock adalah sebagai berikut. (a) Proses berpikir siswa tunagrahita ringan dalam menemukan dan menyusun masalah, yaitu: Dua siswa tersebut sama-sama memulai menyelesaikan masalah dengan membaca soal, siswa hanya diam dan melihat kembali soal, siswa tidak mampu menyebutkan hal yang diketahui dan yang hal yang ditanyakan. Untuk menyelesaikan sesuatu siswa menunggu arahan atas apa yang harus dikerjakan, siswa hanya mampu mengungkapkan sebagian informasi atas hal yang diketahui, sehingga ada informasi yang tidak diungkapkan dan ditulis. Siswa satu kesulitan menyebutkan hal yang ditanya, dengan menunjukkan respon diam kemudian membaca kembali soal, dan siswa satunya dengan melihat kembali soal dan mengungkapkan jawaban terkait operasi hitung. Dalam menyusun strategi pemecahan masalah, dua siswa butuh arahan sehingga salah satu siswa mampu menyusun strategi atas hal yang ditanya dengan menunjukkan respon diam dan melihat kembali soal kemudian baru mampu mengungkapkan dengan mengkaitkan pada operasi hitung, dan siswa satunya dengan mengungkapkan rencana/strategi penyelesaian yang kurang tepat pada langkah awal. (b) Proses berpikir siswa tunagrahita ringan dalam mengembangkan strategi pemecahan masalah, yaitu: Dua siswa sama-sama butuh arahan ketika memulai menyelesaikan permasalahan, siswa satu menyelesaikan masalah sesuai strategi yang telah disusun dengan mengkaitkan pada operasi hitung, tetapi ada siswa satunya kesulitan melaksanakan strategi yang telah disusun dengan melaksanakan strategi yang berbeda. Dalam proses menghitung, siswa menyelesaikan perhitungan dengan cara disusun kebawah dan siswa cenderung menggunakan kedua tangannya sebagai alat bantu hitung. (c) Proses berpikir siswa tunagrahita ringan dalam mengevaluasi solusi, yaitu: Siswa satu melakukan pengecekan kembali jawaban dengan menghitung ulang kembali jawaban dan meyakininya, dan siswa satu lainnya hanya menunjukkan respon dengan melihat sekilas jawaban dan menyakini jawaban yang didapat. (d) Proses berpikir siswa tunagrahita ringan dalam memikirkan serta mendefinisikan kembali masalah dan solusi, yaitu: Dua siswa memberikan respon dengan melihat kembali jawaban dan mengungkapkan bahwa tidak ada ide/cara lain dalam penyelesaian masalah.

Berdasarkan hasil penelitian, maka diberikan saran kepada: (1) guru matematika, dalam pengajaran, ketika siswa tunagrahita ringan dihadapkan pada soal matematika misalnya dalam menyelesaikan soal cerita, maka siswa diberikan arahan langkah awal dalam menyelesaikan masalah untuk mampu menemukan dan menyusun masalah dengan mengetahui hal yang diketahui dan yang ditanyakan pada soal, kemudian membuat strategi/rencana penyelesaian masalah. Setelah siswa selesai menyelesaikan soal, siswa dibimbing untuk mengevaluasi solusi dengan mengecek ulang jawaban yang sudah 
dikerjakan, dimungkingkan ada kesalahan jawaban baik dalam perhitungan atau yang lain, (2) bagi siswa, walaupun mengalami keterlambatan mental siswa tunagrahita ringan mampu dididik dalam bidang akademik, sehingga harus lebih termotivasi dalam mempelajari pelajaran matematika, apalagi terkait soal cerita yang selalu berkaitan dalam kehidupan sehari-hari sehingga mampu dalam mengembangkan kemampuan kognitifnya.

\section{DAFTAR PUSTAKA}

Breen, S.E\& O'shea, A. 2010. Mathematical Thinking and Task Design. Bulletin of Education Mathematics, Halaman 39-49.

Butler, F. M, dkk. Teaching Mathematics to Student With Mild-to-Moderate Metal Retardation: A Review of the Literatur. Journal of American Assocation on Mental Retardation(AAMR). Vol.39, No.1, pp 20-31.

Ilham Sunaryo \& Surtikanti. 2011. Pendidikan Anak Berkebutuhan Khusus. Fakultas Keguruan dan Ilmu Pendididkan Universitas Muhammdiyah Surakarta.

Mohammad Efendi. 2006. Pengantar Psikopedagogik Anak Berkelainan. Jakarta: Bumi Aksara.

Pehkonen, E. 2000. Problem solving in mathematics education in Finlan. www.unige.ch/math/EnsMath/Rome2008/WG2/Papers/PEHKON.pdf. Diunduh tanggal 23 Desember 2012.

Sandie. 2013. Proses Berpikir Siswa Tunagrahita Dalam Memecahkan Masalah Matematika Ditinjau Dari Perbedaan Gender. Tesis. Surakarta: Program Pasca Sarjana Universitas Sebelas Maret.

Santrock, J. W. 2009. Psikologi Pendidikan Edisi 3 Buku 2. Penerjemah Salemba Humanika. Jakarta: Salemba Humanika.

Solso, R. L. dkk. 2007. Psikologi Kognitif Edisi Kedelapan. Penerjemah Erlangga. Jakarta: Erlangga.

Sutjihati Somantri. 2007. Psikologi Anak Luar Biasa. Bandung: PT. Refika Aditama. 